\title{
ОСНОВНІ СУЧАСНІ ПРАКТИЧНІ ТЕНДЕНЦІї ЕВОЛЮЦІЇ СУБ'ЄКТНОГО СКЛАДУ ПРАВОВІДНОСИН У СФЕРІ ПРИКОРДОННОЇ БЕЗПЕКИ УКРАЇНИ
}

Ганьба О. Б.

Метою статmі є аналіз основних сучасних практичних тенденцій еволюції суб'єктного складу правових відносин у сфері прикордонної безпеки України. У статті проаналізовані основні практичні тенденції еволюції правових відносин у сфері прикордонної безпеки України. Наведені приклади їх конкретного прояву в правореалізаційній діяльності зазначеної сфери. Розглядаються стан та якість реалізації конкретних державних програм, що сприяють втіленню в життя згаданих тенденцій. Автором також визначені напрями вдосконалення кадрової політики серед персоналу державних органів сектору безпеки і оборони України, реалізація яких сприятиме поліпшенню суб'єктного складу правовідносин у сфері прикордонної безпеки України. 3'ясовано, що вагомий вклад у стабілізацію безпекового середовища протидії сепаратизму та часткового витіснення потенційних суб'єктів сепаратистських відносин на сході України внесла спеціальна програма, запроваджена СБУ, під назвою «На тебе чекають вдома». Наголошено, що показовою в питаннях оптимізації органів і підрозділів прикордонного патрулювання $\epsilon$ раціональність системи митно-прикордонної служби США, яка обмежується лише дворівневою будовою: 1) сектори; 2) станції (пункти). Зроблено висновок, що: у сучасній практиці правового регулювання відносин у сфері прикордонної безпеки визначились три основні практичні тенденції їхньої еволюції: тенденція розширення суб'єктного складу правовідносин, тенденція його звуження та тенденція витіснення негативних потенційних суб'єктів із зазначеної сфери; наведені та проана лізовані конкретні приклади прояву викладених тенденцій із практики правореалізаційної діяльності досліджуваної сфери; на основі аналізу теоретичних джерел і чинних нормативно-правових актів визначені напрями вдосконалення кадрової політики Державної прикордонної служби України та в інших правоохоронних органах і військових формуваннях сектору безпеки і оборони нашої держави, розв'язання яких сприятиме поліпшенню суб'єктного складу досліджуваних правовідносин.

Ключові слова: суб'єктний склад правовідносин, сфера прикордонної безпеки, сфера національної безпеки, тенденції еволюції суб'єктного складу правовідносин, кадрова політика, напрями вдосконалення кадрової політики.

Целью статьи является анализ основных практических тенденций эволюции субъектного состава правовых отношений в сфере пограничной безопасности Украины. $B$ статье проанализированы основные практические тенденции эволюции правовых отношений в сфере пограничной безопасности Украины. Приведены примеры их конкретного проявления в правореализационной деятельности указанной сферы. Рассматриваются состояние и качество реализачии конкретных государственных программ, способствующих претворению в жизнь упомянутых тенденций. Автором также определены направления совершенствования кадровой политики среди персонала государствен-

Ганьба О. Б., 2019 ных органов сектора безопасности и обороны Украины, реализация которых будет способствовать улучшению субъектного состава правоотношений в сфере пограничной безопасности Украины. Выяснено, что весомый вклад в стабилизацию безопасности среды противодействия сепаратизму и частичного вытеснения потенциальных субъектов сепаратистских отношений на востоке Украины внесла специальная программа, введенная СБУ, под названием «Тебя ждут дома». Отмечено, что показательной в вопросах оптимизации органов и подразделений пограничного патрулирования является рациональность системы таможенно-пограничной службы США, которая ограничивается только двухуровневой системой: 1) сектора; 2) станции (пункты). Сделан вывод, что в современной практике правового регулирования отношений в сфере пограничной безопасности определились три основные практические тенденции их эволюции: тенденция расширения субъектного состава правоотношений, тенденция его сужения и тенденция вытеснения негативных потенциальных субъектов из указанной сферы; приведены и проанализированы конкретные примеры проявления изложенных тенденций на практике правореализационной деятельности исследуемой сферы; на основе анализа теоретических источников и действующих нормативно-правовых актов определены направления совершенствования кадровой политики Государственной пограничной службы Украины и в других правоохранительных органах и воинских формированиях сектора безопасности и обороны нашего государства, решение которых будет способствовать улучшению субъектного состава исследуемых правоотношений.

Ключевые слова: субъектный состав правоотношений, сфера пограничной безопасности, сфера национальной безопасности, тенденции эволюции субъектного состава правоотношений, кадровая политика, направления совершенствования кадровой политики.

The purpose of the article is to analyze the main contemporary practical trends in the evolution of the subjective composition of legal relations in the field of Ukrainian border security. The article analyzes the main practical trends in the evolution of legal relations in the field of border security of Ukraine. Examples of their specific manifestation in the right-realization activity of the specified sphere are given. The state and quality of implementation of specific state programs that contribute to the implementation of these trends are considered. The author also outlines directions of improvement of personnel policy among the personnel of state bodies of the security and defense sector of Ukraine, the implementation of which will improve the subjective composition of legal relations in the field of border security of Ukraine. It has been found out that a special program, introduced by the Security Service of Ukraine, entitled "You're waiting for you at home", made a significant contribution to the stabilization of the safe environment of combating separatism and the partial displacement of potential subjects of separatist relations in eastern Ukraine. It was emphasized that the rationality of the US Customs and Border Patrol sys- 
tem, which is limited to only two-tier structure: 1) sectors; 2) stations (points). It is concluded that: in the current practice of legal regulation of relations in the field of border security, three main practical tendencies of their evolution have been identified: the tendency of expansion of the subjective composition of legal relations, the tendency of its narrowing and the tendency of displacement of negative potential subjects from the specified sphere; specific examples of manifestation of the stated tendencies from the practice of right-realization activity of the investigated sphere are presented and analyzed; on the basis of the analysis of theoretical sources and the current normative legal acts, the directions of improvement of personnel policy in the State Border Guard Service of Ukraine and other law enforcement agencies and military formations of the security and defense sector of our country are determined, the solution of which will help to improve the subjective composition of the investigated legal entities.

Key words: subjective composition of legal relations, border security, national security, tendencies of evolution of subjective legal relations, personnel policy, directions of improvement of personnel policy.

Постановка проблеми та їі актуальність. У сучасних умовах державотворення України важливу роль відіграє якісна правотворча діяльність держави та громадянського суспільства, завдяки якій оновлюється не тільки законодавча база правового регулювання різноманітних сфер життєдіяльності держави, а й створюються умови для розвитку та вдосконалення правових відносин, у тому числі й у сфері прикордонної безпеки України.

Давно доведено, що будь-які правовідносини залишатимуться мертвим статичним явищем, якщо не будуть приведені в рух, у стан реалізації їх учасниками конкретними суб'єктами шляхом належного виконання

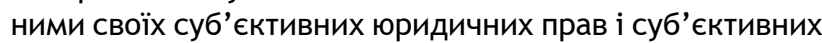
юридичних обов'язків задля задоволення особистісних, суспільних та державних потреб і інтересів, якими у сфері прикордонної безпеки виступають різноманітні приватні та публічні цінності.

У правовідносинах зазначеної сфери їхніми суб'єктами, що представляють інтереси держави, виступають військовослужбовці та працівники Державної прикордонної служби України (далі - ДПСУ) та інших органів сектору безпеки і оборони України, від особистих якостей яких залежить ефективність реалізації змісту конкретних регулятивних, охоронних чи захисних правовідносин.

Тому вдосконалення рівня професійної діяльності персоналу сприятиме підвищенню якості суб'єктного складу правовідносин, що $є$ першочерговим завданням відповідних органів держави.

Аналіз останніх досліджень i публікацій. Проблеми дослідження суб'єктного складу правовідносин як на загальнотеоретичному, так і на галузевому рівні досліджували такі вітчизняні й зарубіжні науковці, як: С.С. Алексєєв, С.Д. Гусарєв, Л.П. Корбут, Л.О. Самілик, І.А. Сердюк, О.Ф. Скакун, АС. Спаський та інші.

Проте загострення сучасних проблем прикордонного безпекового середовища, виникнення нових викликів ізагроз усфері як національноїбезпеки загалом, так іприкордонної безпеки України зокрема потребує подальшого поглибленого дослідження суб'єктного складу правовідносин згаданої сфери шляхом аналізу й узагальнення накопичених наукових надбань з урахуванням військового протистояння на сході нашої держави.
Виходячи з викладеного, метою статті $\epsilon$ аналіз основних сучасних практичних тенденцій еволюції суб'єктного складу правових відносин у сфері прикордонної безпеки України.

Реалізація викладеної мети зумовила потребу вирішення таких завдань:

- окреслити сутність та особливості основних сучасних практичних тенденцій еволюції суб'єктного складу правовідносин у сфері прикордонної безпеки України;

- навести приклади їх реального прояву в правореалізаційній діяльності досліджуваної сфери;

- визначити напрями вдосконалення кадрової політики в ДПСУ та інших правоохоронних органах і військових формуваннях сектору безпеки і оборони України 3 метою поліпшення якості суб'єктного складу правовідносин у зазначеній сфері.

Виклад основного матеріалу. Одним з основних шляхів удосконалення правовідносин у сфері прикордонної безпеки України $\epsilon$, безумовно, всебічне поліпшення їх суб'єктного складу. Вбачається, що проблеми такого поліпшення варто розглядати в контексті трьох, на перший погляд, протирічних практичних тенденцій їхної еволюції, а саме: перша тенденція - розширення суб'єктного складу правових відносин; друга тенденція звуження їх суб'єктного складу; третя тенденція - витіснення небажаних потенційних суб'єктів правових відносин із відповідної правореалізаційної сфери держави.

Зупинимось коротко на висвітленні сутності й особливостей кожної з названих тенденцій.

Перша тенденція - тенденція розширення суб'єктного складу правовідносин зумовлена ускладненням, інтеграцією та модернізацією системи прикордонної безпеки, що проявляється в реалізації положень Стратегії інтегрованого управління кордонами на період до 2025 року, упровадженні європейських норм і стандартів у систему прикордонного контролю, модернізації системи управління ДПСУ та вдосконалення усіх рівнів взаємодії державних, недержавних і зарубіжних органів у сфері прикордонної безпеки, розвитку прикордонної інфраструктури, удосконаленні системи роботи 3 персоналом та іншими чинниками [1].

Окреслені чинники породжують таких потенційно нових індивідуальних і колективних суб'єктів, як національний контактний пункт з перевірки автентичності паспортних документів (перспективний орган); підрозділи швидкого реагування та їхній персонал; ситуаційний центр моніторингу й аналізу міграційних ризиків (перспективний орган); спільні контактні пункти; спільні пункти пропуску на кордоні суміжних держав; робочі групи з прикордонного співробітництва; підрозділи з питань аналізу й управління ризиками та їх посадові особи; спільні слідчі групи та їх посадові особи; тренери-експерти з оцінки якості діяльності суб'єктів інтегрованого управління кордонами та інші суб'єкти, які сприяють забезпеченню прикордонної безпеки, розвитку існуючих та становленню і вдосконаленню перспективних відносин у зазначеній сфері $[1 ; 2]$.

Розширення суб'єктного складу контролюючих і охоронних правовідносин у досліджуваній сфері здійснюється також за рахунок добровільної участі в правоохоронній діяльності представників волонтерських організацій, добровольчих рухів територіальної оборони прикордоння та інших громадських організацій, рівень довіри до яких з боку населення України у 2018 році був 
найвищим і становив близько 66\%, що свідчить про зростаючу роль українського громадянського суспільства в забезпеченні як національної безпеки України загалом, так і прикордонної безпеки зокрема. Це яскраво демонструє громадська акція з припинення незаконних торговельних відносин 3 окупованими районами Донбасу у зв'язку з бездіяльністю місцевої влади, що призвело до блокування з кінця січня 2017 року ветеранами АТО з батальйонів «Донбас» і «Айдар» залізничних шляхів у містах Лисичанську й Гірському, які ведуть на непідконтрольні Україні території [3, с. 81]. Активну участь у реалізації охоронних і захисних відносин у сфері прикордонної безпеки взяли добровольці АТО/ООС, волонтери-постачальники, волонтери-медики, волонтери-ремонтники та інші представники громадянського суспільства [4, с. 119].

Їхня участь у зазначеній діяльності регламентується Законом України від 22 червня 2000 року № 1835-ІІІ «Про участь громадян в охороні громадського порядку і державного кордону» [5]. Зазначений закон потребує доповнення додатковими соціальними гарантіями захисту представників громадськості під час виконання завдань з охорони державного кордону та додатковими матеріальними заходами мотивації та заохочення їх діяльності.

На превеликий жаль, розширення суб'єктного складу адміністративних і кримінально-правових правовідносин охоронного характеру здійснюється і за рахунок збільшення незаконних видобувачів бурштину в районі прикордоння, незаконного переміщення його через кордон тощо [6, с. 321-324].

Об'єктивну закономірність динаміки суб'єктного складу правовідносин у досліджуваній сфері викладає С.О. Філіппов у своїй монографії, сутність якої полягає в залежності поглиблення транскордонного співробітництва із суміжними державами і зростання рівня криміналізації транскордонних відносин та інтернаціоналізації злочинності, з чим ми також погоджуємося [6, с. 261].

Друга тенденція - звуження суб'єктного складу правовідносин, викликана як позитивними, так і негативними факторами. Так, потреба оптимізації структури й системи органів і підрозділів ДПСУ в ході їі модернізації сприяє раціональному скороченню потенційних суб'єктів правовідносин. Сприяє зазначеному процесу також скорочення посадових осіб проміжних управлінських ланок у владній вертикалі системи ДПСУ [7].

Показовою в питаннях оптимізації органів і підрозділів прикордонного патрулювання $\epsilon$ раціональність системи митно-прикордонної служби США, яка обмежується лише дворівневою будовою: 1) сектори; 2) станції (пункти) [8].

Третя тенденція еволюції суб'єктного складу правовідносин у сфері прикордонної безпеки, як уже зазначалося, полягає у витісненні небажаних потенційних суб'єктів із відповідної правореалізаційної сфери держави як силовими, так i несиловими методами. Наочним прикладом такого витіснення може слугувати низка прикладів і з міжнародної та вітчизняної практики правового регулювання відносин у сфері національної безпеки окремих держав. Так, у Латвї та Естонії з метою позбавлення або обмеження виборчого права вороже налаштованих іншомовних громадян, що постійно проживають у цих державах, був запроваджений інститут надання статусу негромадянства з врученням такій особі паспорта негромадянина, згідно з яким вона наділяється майже повним переліком прав громадян зазначених держав, проте у Латвії такі особи фактично позбавлялися виборчих прав, а в Естонії за ними залишалося активне право участі тільки в місцевих виборах. Як результат, інститут негромадянства запобігає проникненню у виборчі органи державної влади та органи місцевого самоврядування деструктивних елементів [9, с. 14].

Іншим прикладом ефективного витіснення небажаних потенційних суб'єктів з участі у відносинах сфери прикордонної безпеки $є$ особливості боротьби з сепаратизмом у Хорватії, де шляхами такого витіснення стали завоювання прихильності місцевого населення завдяки сприянню його соціально-економічному розвитку, перекриття каналів матеріально-технічного та військового постачання сепаратистів, установлення контролю над кордонами, створення місцевих сил самооборони, правдиве, об'єктивне інформування місцевого населення, пропаганда політики умиротворення тощо [9, с. 28-30].

Вагомий вклад у стабілізацію безпекового середовища протидії сепаратизму та часткового витіснення потенційних суб'єктів сепаратистських відносин на сході України внесла спеціальна програма, запроваджена СБУ, під назвою «На тебе чекають вдома». Станом на початок 2019 року нею скористались понад 360 осіб. 303 учасники незаконних військових формувань залишили антиукраїнську сепаратистську діяльність у ДНР/ЛНР, а 232 з них звільнено від кримінальної відповідальності на підставі судових рішень станом на кінець травня 2018 року [10].

Сприяє витісненню та нейтралізації потенційних суб'єктів протиправних корупційних стосунків у сфері прикордонної безпеки персоналу ДПСУ також запровадження та реалізація інституту добровільної відмови від отримання неправомірної вигоди. Так, завдяки мотиваційному впливу зазначеного інституту 785 військовослужбовців ДПСУ у 2018 році свідомо відмовилися від отримання неправомірної вигоди, з них 636 осіб заохочено грошовими преміями [11].

Насамкінець зазначимо, що оновленню та підвищенню якості суб'єктного складу правовідносин у сфері прикордонної безпеки сприятиме узгоджена високоефективна, науково обґрунтована кадрова політика, основними напрямами реалізації якої, на нашу думку, $\epsilon:$ 1) удосконалення законодавства, що регламентує роботу з персоналом ДПсу та інших органів сектору безпеки і оборони держави; 2) підготовка військовослужбовців і працівників у спільних центрах за єдиними уніфікованими стандартами $€ C$ та узгодженими програмами, які відповідають національним потребам і вимогам спільної колективної безпеки країн $€ С$ та інших суміжних держав; 3) адаптація підходів підготовки персоналу до змін оперативного прикордонного середовища з урахуванням кращих європейських практик; 4) підготовка персоналу в змодельованих стресових ситуаціях, відпрацювання дій у закритому просторі, у нічний час, у гірській місцевості та в інших складних випадках, характерних для умов загострення обстановки; 5) підвищення ефективності роботи з кадрами шляхом розроблення і впровадження електронних систем управління персоналом; 6) забезпечення якісного відбору кандидатів на посади в органах і підрозділах 
ДПСу та інших органах сектору безпеки і оборони держави на основі кращих, апробованих практикою методик передових держав сучасного світу; 7) забезпечення належної мотивації персоналу та підвищення високого рівня його соціального, правового та психологічного захисту. Для цього необхідно здійснювати щорічне підбиття підсумків якості роботи персоналу ДПСУ із загальною оцінкою його за п'ятьма критеріями: «незадовільно», «нижче за норму», «норма», «вище за норму», «набагато вище за норму», що широко практикується за кордоном у різних державних структурах. Працівники, які отримали оцінку «вище за норму» та «набагато вище за норму», потенційно претендують на підвищення заробітної плати, отримання премій і заносяться в резерв на призначення на вищу посаду [3, с. 89].

Висновки. Отже, узагальнення вищевикладених положень дає змогу зробити такі висновки:

- у сучасній практиці правового регулювання відносин у сфері прикордонної безпеки визначились три основні практичні тенденції їхньої еволюції: тенденція розширення суб'єктного складу правовідносин, тенденція його звуження та тенденція витіснення негативних потенційних суб'єктів із зазначеної сфери;

- наведені та проаналізовані конкретні приклади прояву викладених тенденцій з практики правореалізаційної діяльності досліджуваної сфери;

- на основі аналізу теоретичних джерел і чинних нормативно-правових актів визначені напрями вдосконалення кадрової політики в ДПСУ та інших правоохоронних органах і військових формуваннях сектору безпеки і оборони нашої держави, розв'язання яких сприятиме поліпшенню суб'єктного складу досліджуваних правовідносин.

\section{Література}

1. Про схвалення Стратегії інтегрованого управління кордонами на період до 2025 року : розпорядження Кабінету Міністрів України від 24 липня 2019 року № 687-p. URL: https://zakon.rada.gov.ua/laws/show/687-2019-\%D1\%80.

2. Про затвердження плану заходів на 2020-2022 роки щодо реалізації Стратегії інтегрованого управління кор- донами на період до 2025 року : розпорядження Кабінету Міністрів України від 27 грудня 2019 року № 1409-p. URL: https://zakon.rada.gov.ua/laws/show/1409-2019-\%D1\%80.

3. Ганьба Б.П., Ганьба О.Б. Окремі проблеми державного управління та шляхи й заходи його модернізації в зрізі сучасних реформ і військового протистояння на Сході України. Процес модернізації системи державного управління: конституційний, адміністративний та фінансовий аспекти : колективна монографія / за заг. ред. А.С. Нестеренко. Одеса : Видавничий дім «Гельветика», 2017. С. 79-91.

4. Аналітична доповідь до Щорічного Послання Президента України до Верховної Ради України «Про внутрішнє та зовнішнє становище України в 2018 році». Київ : НІСД, 2018. 688 с.

5. Про участь громадян в охороні громадського порядку і державного кордону : Закон України від 22 червня 2000 року № 1835-ІІІ. Відомості Верховної Ради України. 2000. № 40. СТ. 338.

6. Філіппов С.О. Протидія транскордонній злочинності: глобальний контекст і реалії України : монографія. Одеса : Фенікс, 2019. 452 с.

7. Реформа Держприкордонслужби: Чи піде на користь тотальне скорочення генералів. URL: https://www.depo.ua/ ukr/war/reforma-derzhprikordonsluzhbi-chi-pide-na-koristskorochennya-kilkosti-generaliv-201912251086216.

8. Border Patrol Sectors. URL: https://www.cbp.gov/ border-security/along-us-borders/border-patrol-sectors.

9. Міжнародний досвід боротьби із сепаратизмом: висновки для України : аналіт. доп. / О.О. Резнікова та ін. Київ : НІСД, 2016. 52 с.

10. Програма Служби безпеки України «На тебе чекають вдома». URL: https://ssu.gov.ua/ua/pages/206.

11. Про оголошення та введення в дію рішення колегії Адміністрації Державної прикордонної служби України від 7 лютого 2019 року № 4 «Про підсумки оперативно-службової діяльності Державної прикордонної служби України у 2018 році та завдання на 2019 рік» : наказ Адміністрації Державної прикордонної служби України від 18 лютого 2019 року № 14.

Ганьба О. Б., кандидат юридичних наук 